\title{
LEARNING MODELS USING PROBING PROMPTING TECHNIQUES ASSISTED BY BLENDED LEARNING EDMODO TO IMPROVE MATHEMATICAL UNDERSTANDING ABILITY
}

\author{
Rahmawati $^{1)}$, Jayanti ${ }^{2)}$ \\ ${ }^{1,2}$ Universitas PGRI Palembang \\ Email : rahmawatisuandi@yahoo.co.id
}

\begin{abstract}
This study aims to see an increase in the ability of mathematical understanding of students using probing learning models prompting assisted by edmodo blended learning. In this model the researcher presents a series of questions that are digging and guiding so that a thinking process that links each student's knowledge and experience with new knowledge is occurring. learned. Research subject of 3rd Semester Student in Mathematics and Teacher Training Faculty, University of PGRI Palembang. This research method is Quasi-Experimental. The data of this study are of two types. Quantitative data was obtained through analysis of student answers on the KPM test which was carried out pretest and posttest, and qualitative data were obtained from observations of lecturer and student activities, and the results of interviews with students. Data analysis used: doing descriptive analysis of data and calculating normalized gain (normalized gain) pretest and posttest, Testing requirements analysis is the data normality test and variance homogeneity test of the whole quantitative data, and hypothesis testing in this study t test, t-test, MannWhitney U test, one-way ANAVA test or Kruskal-Wallis test. Hypothesis testing using SPSS-20 for Windows. The results of the data analysis concluded that 1) the increase in the ability of mathematical understanding of students who get learning by probing prompting assisted by edmodo blended learning is better than students who get conventional learning in terms of (a). all students (b) .KAM students
\end{abstract}

Keywords: Probing Prompting, Mathematical Understanding, Edmodo Blended Learning

\section{PENDAHULUAN}

Langkah-langkah penyelesaian persoalan dalam matematika yang sering dilakukan selama ini oleh siswa adalah dengan cara menghapal rumus matematika yang ada, sehingga siswa merasa terbebani dengan banyaknya rumus yang diberikan, hal ini yang menyebabkan pelajaran matematika menjadi menakutkan, dan susah untuk dipelajari (Ferdianto 2014) dan Sebagaimana diungkapkan oleh (Asmin 2003) dalam pembelajaran matematika di Indonesia masih banyak guru yang melakukan proses pembelajaran matematika di sekolah dengan pembelajaran konvensional, yakni guru secara aktif mengajarkan matematika kemudian memberi contoh dan latihan sedangkan siswa mendengarkan, mencatat, dan mengerjakan latihan yang diberikan oleh guru. Dalam hal ini, siswa hanya berusaha menghafalkan pengetahuan yang diterimanya untuk menyelesaikan persoalan yang diberikan, padahal menghafal bukan merupakan jawaban dalam matematika, khusunya ketika siswa tidak mengerti. dan juga menurut Muhsin (2013) bahwa pembelajaran yang selama ini dilakukan pada sekolah tersebut kurang memberi kesempatan kepada siswa untuk mengkontruksi dan menemukan sendiri pengetahuannya, pembelajaran yang berlangsung hanya melalui satu arah dan hanya berpusat kepada guru sebagai sumber informasi pengetahuan. 
Semua tanggapan tersebut berkembang dalam masyarakat tentang matematika, semua itu menuntut guru untuk meningkatkan mutu pendidikan mulai dari kreativitas berpikir, inovasi dalam pembelajaran, teknik dan metode yang tepat dalam pembelajaran, pemahaman karakter terhadap siswa dan penguasaan siswa yang baik sangat diperlukan dalam pengelolaan kelas. Hal ini juga sangat diperlukan dalam pemahaman konsep, Dengan meningkatnya pemahaman konsep siswa meningkat pula kualitas siswa.

Namun pelaksanaannya masih mengalami berbagai tantangan maupun permasalahan. Ningsih (2012) menyatakan bahwa masalah utama yang sering dihadapi pada pelajaran matematika adalah rendahnya kemampuan pemahaman konsep siswa. Diduga yang menjadi penyebab dari permasalahan tersebut yaitu pendekatan pembelajaran yang dipakai selama ini masih menggunakan pendekatan tradisional yang menekankan pada latihan mengerjakan soal serta menggunakan rumus. Menurut Eka Eka fauziyah (2014) Kesulitan memahami konsep matematika umumnya di sebabkan karena sifat dari matematika yang memiliki objek abstrak yang sulit dicerna anak. Sejalan dengan itu menurut Oktavia (2016) yaitu masih banyak perguruan tinggi yang lebih menekankan kepada transformasi pengetahuan sebanyak-banyaknya kepada mahasiswa daripada mentransformasikan ketrampilan yang dibutuhkan mahasiswa dalam belajar, sehingga masih banyak mahasiswa mengalami kesulitan dalam belajar persamaan diferensial.

Berdasarkan pemaparan tersebut, kemampuan pemahaman sangat diperlukan bagi seseorang. Hal ini dipertegas dengan adanya pernyataan NCTM (Nila, 2008) bahwa pemahaman matematis merupakan aspek yang sangat penting dalam prinsip pembelajaran matematika dan pemahaman matematik lebih bermakna jika dibangun oleh siswa sendiri. Kurniawan (2012) mengemukakan bahwa kemampuan pemahaman merupakan salah satu faktor yang memberikan kontribusi dan turut menentukan keberhasilan pelajar dalam menyelesaikan masalah Nana Sudjana (2011:24) menjelaskan bahwa pemahaman merupakan tingkat hasil belajar yang lebih tinggi daripada pengetahuan yang diperoleh, perlu adanya mengenal atau mengetahui untuk dapat memahami. Sari (2012: 20) bahwa pemahaman matematika dapat dikatakan sebagai pondasi dalam mengembangkan pembelajaran matematika. Bani (2011) menyatakan bahwa kemampuan pemahaman matematis adalah salah satu tujuan penting dalam pembelajaran. Hal ini memberikan pengertian bahwa materi-materi yang diajarkan kepada siswa bukan hanya sebagai hafalan, namun diharapkan siswa dapat lebih mengerti akan konsep materi pelajaran itu sendiri.

Dari berbagai hasil penelitian yang telah dilakukan bahwa permasalahan tersebut dapat diselesaikan dengan suatu metode yang bisa dijadikan solusi untuk meningkatkan kemampuan pemahaman matematis siswa yaitu pembelajaran dengan menggunakan teknik probing prompting. Penelitian yang dilakukan oleh Suhendar (2012) yang menyimpulkan bahwa probing-prompting dapat meningkatkan pemahaman konsep matematis siswa, Atika weny (2013) pemahaman konsep matematis siswa pada kelas yang menggunakan model 
pembelajaran probing-prompting lebih baik dari-pada pemahaman konsep matematis siswa pada kelas yang menggunakan model pembelajaran konvensional, Afifah Yuli (2014) pembelajaran dengan Teknik Probing Prompting yang dapat mengubah persepsi siswa tentang matematika dan mengubah siswa menjadi lebih aktif dalam proses belajar mengajar, Ningsih (2016) model blended learning dalam upaya meningkatkan hasil belajar matematika mahasiswa, Alfy siti (2015) Model pembelajaran dengan menggunakan blended learning mampu memberikan perubahan hasil belajar siswa dan dapat digunakan guru dalam kegiatan pembelajaran guna menciptakan suasana pembelajaran baru.

Menurut Suherman (2008), probing-prompting adalah pembelajaran dengan cara guru menyajikan serangkaian pertanyaan yang sifatnya menggali dan menuntun sehingga terjadi proses berpikir yang mengaitkan pengetahuan setiap siswa dan pengalamannya dengan pengetahuan baru yang sedang dipelajari. Dalam model pembelajaran ini, setiap siswa dibiasakan agar dapat mengonstruksi konsep, prinsip, dan aturan menjadi pengetahuan baru sehingga pengetahuan baru tidak diberitahukan. Dengan demikian, pemahaman konsep siswa akan menjadi lebih baik sehingga siswa dapat menyerap, menguasai, dan menyimpan materi yang dipelajarinya dalam jangka waktu yang lama.

Menurut atika weny (2013), Model pembelajaran probing-prompting dapat mendorong siswa lebih aktif berpikir karena melalui pertanyaan-pertanyaan yang diberikan guru, siswa dihadapkan pada suatu masalah yang membuatnya untuk berpikir dalam menyelesaikan masalah tersebut. Selain itu, model pembelajaran probing-prompting dapat mengembangkan keberanian dan keterampilan siswa dalam menjawab pertanyaan dan mengemukan pendapat, dapat memusatkan dan menarik perhatian siswa dengan pertanyaan-pertanyaan yang diberi-kan guru, serta guru dapat meng-arahkan siswa pada suatu diskusi karena dalam kegiatan pembelajaran akan timbul perbedaan pendapat antar siswa. Model pembelajaran blended learning menurut Garrison \& Vaughan (2008:5) merupakan model pembelajaran yang mengkombinasikan antara pembelajaran tatap muka dan pembelajaran online.

Berdasarkan data empiris diatas, dan secara teoritis bahwa siswa dan mahasiswa dapat belajar aktif menggunakan pembelajaran dengan teknik probing prompting, berbantuan blended learning di mana mahasiswa dapat mengkontruksi pengetahuannya dengan kebebasan mengajukan ide-ide dari pertanyaanpertanyaan yang dibuat oleh guru agar siswa dan mahasiswa dapat meningkatkan kemampuan pemahanam matematis.

Rumusan masalah dalam penelitian ini adalah "Apakah peningkatan kemampuan pemahaman mahasiswa calon guru yang mendapat model pembelajaran dengan menggunakan teknik probing prompting berbantuan edmodo blended learning lebih baik daripada mahasiswa calon guru yang mendapat pembelajaran konvensional ditinjau (a) keseluruhan mahasiswa; dan (b) KAM (tinggi, sedang, dan rendah)? Dan Tujuan dari penelitian ini adalah Peningkatan kemampuan pemahaman mahasiswa setelah mendapat model pembelajaran dengan menggunakan teknik probing prompting berbantuan edmoda blended learning dan pembelajaran konvensional ditinjau dari: (a) keseluruhan mahasiswa; 
dan (b) KAM (tinggi, sedang, dan rendah).

Berdasarkan uraian diatas, penulis tertarik untuk melakukan penelitian dengan judul "Model Pembelajaran dengan Menggunakan Teknik Probing Prompting berbantuan Edmodo Blended Learning untuk Meningkatkan Kemampuan Pemahaman matematis Mahasiswa Semester 3 FKIP Matematika Universitas PGRI Palembang".

\section{METODE PENELITIAN}

Penelitian ini merupakan penelitian Quasi-Experimental karena subjek tidak dikelompokkan secara acak, tetapi diterima apa adanya (Ruseffendi,2005). Pemilihan tipe Quasi-Experimental ini dengan pertimbangan bahwa kelas yang ada telah terbentuk sebelumnya dan mahasiswa telah mendaftar sesuai dengan kurikulum yang ada, sehingga tidak dilakukan lagi pengelompokan secara acak.

Pada penelitian ini, peneliti memberikan perlakuan kepada subjek penelitian untuk selanjutnya ingin diketahui pengaruh perlakuan tersebut. Perlakuan tersebut adalah pembelajaran dengan menggunakan teknik probing prompting berbantuan edmodo blended learning yang diterapkan pada kelas eksperimen. Kemampuan yang diukur pada penelitian ini adalah kemampuan pemahaman matematis (KPM).

Desain penelitian yang digunakan adalah desain kelompok kontrol pretes dan postes non-ekivalen atau Nonequivalent Pre-Test and Post-Test ControlGroup Design

(Creswell, 2012). Secara ringkas desain eksperimen tersebut dapat digambarkan sebagai berikut.

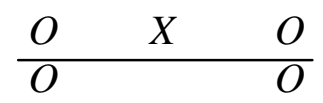

Keterangan:

$O \quad$ : Pretes/postes tentang pemahaman matematis

$X \quad$ : Perlakuan berupa pembelajaran Probing Prompting berbantuan edmodo blended learning

Variabel dalam penelitian ini terdiri dari variabel bebas, variabel terikat, dan variabel kontrol. Variabel bebasnya adalah pembelajaran dengan menggunakan teknik probing prompting berbantuan edmodo blended learning (PPPBL). Variabel terikatnya adalah kemampuan pemahaman matematis (KPM). Variabel kontrolnya adalah kemampuan awal mahasiswa (KAM). Berdasarkan kemampuan awal mahasiswa, diperoleh tiga kategori KAM yaitu: kategori KAM rendah, KAM sedang, dan KAM tinggi. Kemampuan awal mahasiswa diperoleh dari hasil tes yang materinya merupakan materi prasyarat dari mata kuliah persamaan diferensial. Variabel terikat dikaji secara lebih komprehensif, ditinjau dari pembelajaran, KAM, dan keseluruhan mahasiswa. Keterkaitan antara variabel-variabel penelitian yaitu variabel bebas, variabel terikat, dan variabel 
kontrol dinyatakan dalam bentuk model Weiner pada Tabel 1.

Tabel 1. Kemampuan Pemahaman Matematis, Pembelajaran, dan Kemampuan Awal Mahasiswa

\begin{tabular}{|c|c|c|}
\hline Kelompok & \multicolumn{2}{|c|}{ KPM } \\
\hline KAM & PPPBL & PK \\
\hline Rendah (R) & KPM-PPPBL-R & KPM-PK-R \\
\hline Sedang (S) & KPM-PPPBL-S & KPM-PK-S \\
\hline Tinggi (T) & KPM-PPPBL-T & KPM-PK-T \\
\hline Keseluruhan(L) & KPM-PPPBL-L & KPM-PK-L \\
\hline
\end{tabular}

Keterangan :

KPM : Kemampuan Pemahaman Matematis

PPPBL : Pembelajaran dengan menggunakan Probing Prompting berbantuan edmodo Blended Learning

PK : Pembelajaran konvensional

\section{Populasi dan Sampel Penelitian}

Populasi dalam penelitian ini adalah mahasiswa Program Studi Pendidikan Matematika Universitas PGRI Palembang, sedangkan sampel adalah mahasiswa Program Studi Pendidikan Matematika yang mengikuti perkuliahan Persamaan diferensial pada semester genap dan ganjil, tahun 2017-2018. Teknik pengambilan sampel yang digunakan adalah purposive sampling. Penggunaan teknik purposive ini dilakukan karena pemilihan sampel dengan tujuan tertentu, yaitu mahasiswa yang mengikuti mata kuliah Persamaan diferensial yang terdaftar pada semester ganjil dan genap tahun 2017-2018 Pemilihan mata kuliah Persamaan diferensial ini dilakukan karena diduga bahwa materi yang terdapat mata kuliah ini cocok dengan kemampuan yang ingin ditingkatkan (Pemahaman matematis). Selain itu mata kuliah Persamaan diferensial ini dianggap mampu mengakomodasi pemahaman mahasiswa karena memiliki karakteristik sebagai berikut: (1) materi yang bersifat abstrak; (2) lebih menekankan pada aspek penalaran deduktif; serta (3) memerlukan pemahaman secara analitik dalam pembelajarannya.

\section{Teknik Pengumpulan dan Analisis Data}

Data dalam penelitian ini ada dua jenis, yaitu data kuantitatif dan data kualitatif. Data kuantitatif diperoleh melalui analisis terhadap jawaban mahasiswa pada tes KPM yang dilakukan sebelum (pretes) dan sesudah (postes) kegiatan pembelajaran. Data kualitatif diperoleh dari hasil observasi terhadap aktivitas dosen dan mahasiswa, dan hasil wawancara dengan mahasiswa. Data kualitatif dianalisis secara deskriptif untuk mendukung kelengkapan data kuantitatif.

Data kuantitatif ditabulasi dan dianalisis melalui tiga tahap, yaitu:

1. Tahap pertama: melakukan analisis deskriptif data dan menghitung gain ternormalisasi (normalized gain) pretes dan postes.

2. Tahap kedua: menguji persyaratan analisis statistik parametrik yang diperlukan sebagai dasar dalam pengujian hipotesis. Pengujian persyaratan analisis dimaksud adalah uji normalitas data dan uji homogenitas varians 
keseluruhan data kuantitatif.

3. Tahap ketiga: menguji keseluruhan hipotesis. Secara umum, uji hipotesis yang digunakan dalam penelitian ini adalah uji t, uji-t , uji Mann-Whitney U, uji ANAVA satu jalur atau uji Kruskal-Wallis. Keseluruhan pengujian hipotesis tersebut menggunakan paket Program statistik SPSS-20 for Windows

\section{HASIL PENELITIAN DAN PEMBAHASAN}

Hasil dari penelitian adalah pembelajaran dengan menggunakan model mind mapping berbantuan edmodo blended learning lebih baik dari pada pembelajaran secara konvensional untuk meningkatkan kemampuan pemecahan masalah matematis siswa kelas vii materi suku banyak di MTs. Al-Hilaliyah Palembang.

\section{Pembahasan}

\section{Tes Kemampuan Pemahaman Matematis (KPM)}

Untuk memperoleh gambaran hasil KPM mahasiswa, data dianalisis secara deskriptif untuk mengetahui rerata dan simpangan baku skor pretest, postes dan ngain KPM mahasiswa berdasarkan pembelajaran, KAM, dan secara keseluruhan. Statistik deskriptif data KPM mahasiswa selengkapnya disajikan pada tabel 4.

Sebelum melakukan uji tersebut terlebih dahulu dilakukan uji prasyarat analisis, yaitu uji normalitas data dan uji homogenitas varians. Rangkuman hasil uji normalitas dan uji homogenitas disajikan pada tabel 2 dan tabel 3.

Tabel 2. Uji Normalitas Data Peningkatan Kemampuan Pemahaman Matematis berdasarkan Pembelajaran dan KAM

\begin{tabular}{|c|c|c|c|c|c|}
\hline $\begin{array}{c}\text { Kelompok } \\
\text { KAM }\end{array}$ & Pembelajaran & $N$ & K-S & Sig & $\mathrm{H}_{0}$ \\
\hline \multirow{2}{*}{ Keseluruhan } & PPPBL & 36 & 0.640 & 0.808 & diterima \\
\cline { 2 - 6 } & PK & 34 & 0.573 & 0.898 & diterima \\
\hline \multirow{2}{*}{ Tinggi } & PPPBL & 8 & 0.621 & 0.835 & diterima \\
\cline { 2 - 6 } & PK & 4 & 0.410 & 0.996 & diterima \\
\hline \multirow{2}{*}{ Sedang } & PPPBL & 24 & 0.702 & 0.708 & diterima \\
\cline { 2 - 6 } & PK & 21 & 0.596 & 0.869 & diterima \\
\hline \multirow{2}{*}{ Rendah } & PPPBL & 4 & 0.393 & 0.998 & diterima \\
\cline { 2 - 6 } & PK & 9 & 0.812 & 0.525 & diterima \\
\hline
\end{tabular}

$\mathrm{H}_{0}$ : Data peningkatan KPM berdasarkan pembelajaran berdistribusi normal

Tabel 3. Uji Homogenitas Varians Populasi Peningkatan KPM berdasarkan Pembelajaran KAM

\begin{tabular}{|c|c|c|c|}
\hline Kelompok KAM & $\begin{array}{c}\text { Statistik Levene } \\
(\mathrm{F})\end{array}$ & Sig & $\mathrm{H}_{0}$ \\
\hline Keseluruhan & 0.010 & 0.919 & Ditolak \\
\hline Tinggi & 11.633 & 0.007 & Diterima \\
\hline
\end{tabular}




\begin{tabular}{|c|c|c|c|}
\hline Sedang & 0.215 & 0.645 & Diterima \\
\hline Rendah & 5.260 & 0.043 & Diterima \\
\hline
\end{tabular}

$\mathrm{H}_{0}$ : Varians antar kelompok data peningkatan KPM homogen

Tabel 4. Uji perbedaan Rerata Data Peningkatan KPM Berdasarkan Pembelajaran dan KAM

\begin{tabular}{|c|c|c|c|c|c|}
\hline $\begin{array}{c}\text { Kelompok } \\
\text { KAM }\end{array}$ & Pembelajaran & Rerata & $t$ & Sig & $\mathrm{H}_{0}$ \\
\hline Keseluruhan & PPPBL & 0.608 & -7.708 & 0.006 & Ditolak \\
\cline { 2 - 4 } & PK & 0.4020 & & & \\
\hline \multirow{2}{*}{ Tinggi } & PPPBL & 0.7640 & -4.197 & 0.002 & Ditolak \\
\cline { 2 - 4 } Sedang & PK & 0.4720 & & & Ditolak \\
\cline { 2 - 4 } & PPPBL & 0.5596 & -5.464 & 0.000 & Ditolak \\
\hline \multirow{2}{*}{ Rendah } & PP & 0.4324 & & & \\
\cline { 2 - 3 } & PPBL & 0.5860 & -5.828 & 0.000 & \\
\hline
\end{tabular}

$\mathrm{H}_{0}$ : Tidak terdapat perbedaan rerata skor peningkatan KPM antara kedua kelompok

Pada tabel 4 terlihat bahwa secara keseluruhan mahasiswa yang mendapatkan pelajaran dengan menggunakan teknik probing prompting berbantuan edmodo blended learning menunjukkan peningkatan KPM yang lebih tinggi daripada mahasiswa yang mendapatkan pembelajaran konvensional. Hal tersebut didukung pula oleh rerata postesnya. Pada tabel 4, nampak bahwa mahasiswa yang mendapatkan pembelajaran dengan menggunakan teknik probing prompting menunjukan rerata postes yang lebih besar daripada mahasiswa yang mendapatkan pembelajaran konvensional.

Untuk mengetahui apakah perbedaan peningkatan KPM mahasiswa yang mendapatkan pembelajaran dengan menggunakan teknik probing prompting berbantuan edmodo blended learning dan mahasiswa yang mendapatkan pembelajaran konvensional, baik ditinjau secara keseluruhan berdasarkan pembelajaran dan KAM diajukan hipotesis berikut :

\section{Hipotesis 1:}

Mahasiswa yang mendapatkan pembelajaran dengan menggunakan teknik probing prompting berbantuan edmodo blended learning memperoleh peningkatan kemampuan pemahaman matematis lebih baik daripada mahasiswa yang mendapatkan pembelajaaran dengan konvensional ditinjau dari keseluruhan.

\section{Kesimpulan 1 :}

Berdasarkan hasil analisis uji perbedaan rerata peningkatan dan rerata peningkatan KPM mahasiswa yang mendapatkan pembelajaran dengan menggunakan teknik probing prompting berbantuan edmodo blended learning dan mahasiswa yang mendapatkan pembelajaran dengan pembelajaran konvensional, dapat disimpulkan bahwa secara keseluruhan peningkatan KPM mahasiswa yang mendapatkan pembelajaran dengan menggunakan teknik probing prompting berbantuan edmodo blended learning lebih baik daripada mahasiswa yang mendapatkan pembelajaran konvensional. 


\section{Hipotesis 2:}

Mahasiswa yang mendapatkan pembelajaran dengan menggunakan teknik probing prompting berbantuan edmodo blended learning lebih baik daripada mahasiswa yang mendapatkan pembelajaran konvensional ditinjau dari KAM tinggi

\section{Kesimpulan 2:}

Dengan memperhatikan nilai rerata KPM dan hasil uji statistik uji perbedaan dikedua kelompok data peningkatan KPM mahasiswa berdasarkan KAM tinggi dapat disimpulkan bahwa peningkatan KPM mahasiswa yang mendapatkan pembelajaran dengan menggunakan teknik probing prompting berbantuan edmodo blended learning lebih baik daripada mahasiswa yang mendapatkan pembelajaran dengan pembelajaran konvensional ditinjau dari KAM tinggi.

\section{Hipotesis 3:}

Mahasiswa yang mendapatkan pembelajaran dengan menggunakan teknik probing prompting berbantuan edmodo blended learning lebih baik daripada mahasiswa yang mendapatkan pembelajaran konvensional ditinjau dari KAM sedang

\section{Kesimpulan 3:}

Dengan memperhatikan nilai rerata KPM dan hasil uji statistik uji perbedaan dikedua kelompok data peningkatan KPM mahasiswa berdasarkan KAM sedang dapat disimpulkan bahwa peningkatan KPM mahasiswa yang mendapatkan pembelajaran dengan menggunakan teknik probing prompting berbantuan edmodo blended learning lebih baik daripada mahasiswa yang mendapatkan pembelajaran dengan pembelajaran konvensional ditinjau dari KAM sedang.

\section{Hipotesis 4:}

Mahasiswa yang mendapatkan pembelajaran dengan menggunakan teknik probing prompting berbantuan edmodo blended learning lebih baik daripada mahasiswa yang mendapatkan pembelajaran konvensional ditinjau dari KAM rendah

\section{Kesimpulan 4:}

Dengan memperhatikan nilai rerata KPM dan hasil uji statistik uji perbedaan dikedua kelompok data peningkatan KPM mahasiswa berdasarkan KAM rendah dapat disimpulkan bahwa peningkatan KPM mahasiswa yang mendapatkan pembelajaran dengan menggunakan teknik probing prompting berbantuan edmodo blended learning lebih baik daripada mahasiswa yang mendapatkan pembelajaran dengan pembelajaran konvensional ditinjau dari KAM rendah.

Pada tabel 2. Terlihat bahwa nilai probobilitas (Sig), pada pembelajaran probing prompting berbantuan edmodo blended learning (PPPBL) dan pembelajaran konvensional (PK) lebih besar dari 0,05 yang berarti hipotesis nol diterima. Dengan kata lain data peningkatan kemampuan pemahaman matematis (KPM) pada kelompok PPPBL dan PK berdistribusi normal. Begitu juga halnya dengan uji homogenitas pada tabel 3, varians data antar kelompok homogen. Karena data berdistribusi normal dan homogen, maka untuk mengetahui apakah terdapat perbedaan rerata peningkatan KPM antar kedua kelompok pembelajaran 
(PPPBL dan PK) dapat dilakukan dengan mengunakan uj-t. Ringkasan hasil uji-t dapat dilihat pada tabel 4.

Berdasarkan tabel 4 terlihat bahwa nilai signifikansi statistik uji-t sebesar 0,000. Nilai signifikansi ini lebih kecil dari taraf signifikansi 0,05 sehingga hipotesis ditolak. Ini berarti terdapat perbedaan yang signifikansi antara rerata data peningkatan KPM mahasiswa yang mendapatkan pembelajaran dengan menggunakan teknik probing prompting berbantuan edmodo blended learning dan yang mendapatkan pembelajaran konvensional pada taraf signifikansi $\alpha=0,05$.

\section{SIMPULAN DAN SARAN}

Simpulan

1. Peningkatan kemampuan pemahaman matematis siswa yang mendapat pembelajaran dengan menggunakan teknik probing prompting berbantuan edmodo blended learning lebih baik daripada siswa yang mendapat pembelajaran konvensional ditinjau dari keseluruhan.

2. Peningkatan kemampuan pemahaman matematis siswa yang mendapat pembelajaran dengan menggunakan teknik probing prompting berbantuan edmodo blended learning lebih baik daripada siswa yang mendapat pembelajaran konvensional ditinjau dari KAM mahasiswa.

\section{DAFTAR PUSTAKA}

Afifah, Yuli (2014) Pengaruh Teknik Pembelajaran Probing Prompting Terhadap Pemahaman Konsep dan Keterampilan Berfikir Matematika Siswa Kelas VIII MTsN Jambewangi Selopuro Blitar.

Alfi, Siti. (2015). "Pengaruh Model Pembelajaran Blended. Learning Terhadap Hasil Belajar Mata Pelajaran IPS Siswa Di SMPN 37. Jakarta repository.uinjkt.ac.id/...SITI\%20ALFI\%20SYAHRIN\%20-\%20FI...

Ambarwati (2015). Penerapan Pembelajaran Matematika Teknik Probing Prompting Untuk Meningkatkan Kemampuan Komunikasi Matematika Siswa Smp Negeri 4 Tuban, skripsi universitas islam negeri sunan ampel surabaya

Arumsari,D (2010). Pengaruh pendekatan open ended terhadap kemampuan pemahaman matematis siswa sekolah menengah pertama Skripsi pada Jurusan Matematika FKIP UNSWAGATI. Tidak diterbitkan

Asmin. 2003. Implementasi Pem-belajaran Matematika Realistik dan Kendala yang Muncul di Lapangan. Jurnal Pendi-dikan dan Kebudayaan. No. 44.

Atika, Weny dkk. (2013). Efektivitas Model Pembelajaran Probing-Prompting Ditinjau Dari Pemahaman Konsep Matematis Siswa, Jurnal.Fkip Vol 1, No 4 Pendidikan

Matematika, Universitas Lampung

Bani, A. (2011). Meningkatkan kemampuan pemahaman dan penalaran matematik siswa sekolah menengah pertama melalui pembelajaran penemuan terbimbing, SPS UPI,

Bandung. UPI:Bandung.

Creswell. (2009). Research Design Pendekatan Kualitatif, Kuantitatif, dan 
Mixed Edisi Ketiga. Yogyakarta: Pustaka Pelajar.

Dahar, R., W. (2011). Teori-teori Belajar dan Pembelajaran. Jakarta: Erlangga

Danaryanti (2016). Penerapan model probing prompting learning Untuk meningkatkan kemampuan koneksi matematis siswa smp , EDU-MAT Jurnal Pendidikan Matematika Universitas Lambung Mangkurat, Volume 4, Nomor 1, April 2016, hlm 8 - 14

Depdiknas. (2007). Peraturan Menteri Pendidikan Nasional No.22 Tahun 2007 Tentang Standar Isi. Jakarta: BNSP.

Eka, Fauziyah. (2014) Peningkatan Kemampuan Pemahaman Konsep Matematika Melalui

Pendekatan Open-Ended Bagi Siswa Kelas Viii Semester Genap Smp Muhammadiyah $\quad 10 \quad$ Surakarta Tahun 2013/2014. Http://Eprints.Ums.Ac.Id/32974/21/9\%20naskah\%20publikasi.Pdf

Ferdianto, F dan Ghanny. (2014). Meningkatkan kemampuan pemahaman matematis siswa Melalui problem posing. Jurnal Euclid, ISSN 235517101, vol.1, No.1, pp. 1-59 @Prodi Pendidikan Matematika Unswagati Cirebon

Garrison, D. R., \& Vaughan, N. D., 2008. Blended Learning in Higher Education : Framework, principles and guidelines. San Fransisco: Josey-Bass

Indah Cahyani, Nur. (2010) Skripsi : Keefektifan penerapan teknik probing prompting dalam pemahaman siswa pada materi pelajaran al-Islam di SMP Muhammadiyah 2 Taman Sepanjang. Surabaya :UINSA.

Kesumawati, Nila. (2010). Peningkatan Kemampuan Pemahaman, Pemecahan Masalah, dan Disposisi Matematis Siswa SMP Melalui Pendekatan Matematika Realistik Indonesia. Disertasi Pendidikan Matematika SPS UPI.

Kurniawan, Eko (2012). Mathematical Thinking. Tersedia: eko-kurniawanprasetio.blogspot.com. diakses 4 oktober 2016.

Muhsin, dkk. (2013). Peningkatan Kemampuan Pemahaman Dan Pemecahan Masalah

Matematis Melalui Pembelajaran Dengan Pendekatan Kontekstual. Jurnal Peluang, Volume 2, Nomor 1, ISSN: 2302-5158 13. Magister Pendidikan Matematika Program Pascasarjana Unsyiah Banda Aceh

Ningsih, P. R. (2012). Penerapan metode realistic mathematics education (RME) pada pokok bahasan perbandingan senilai dan berbalik nilai di Kelas VII E SMP Ipiems Surabaya. Gamatika, 3(2).

Ningsih, Yunika \& Jayanti, J. (1). Hasil Belajar Mahasiswa Melalui Penerapan Model Blended Learning Pada Mata Kuliah Persamaan Diferensial. Jurnal Pendidikan Matematika RAFA, 2(1), 1-11. Retrieved from http://jurnal.radenfatah.ac.id/index.php/jpmrafa/article/view/1237

Sari, V. T. A. (2012). Pengaruh Pembelajaran Reciprocal, Kooperatif tipe NHT, dan Langsung terhadap Kemampuan Pemahaman Matematis Siswa SMP. Jurnal Pendidikan Sigma Didaktika, Vol. 1 No. 1 Tahun 2012. 20-32 
Sudjana, Nana. 2011. Penilaian Proses Hasil Belajar Mengajar. Bandung: Remaja Rosda karya

Suhendar, Agus. 2012. Penerapan Teknik Pembelajaran Pro-bing Prompting dalam Meningkatkan Kemampuan Pe-mahaman Konsep Matematis Siswa SMA. Skripsi pada Jurusan Pendidikan Mate-matika UPI Bandung: Tidak diterbitkan.

Suherman, E. 2008. Belajar dan Pembelajaran Matematika. Bandung: Tidak diterbitkan.

Nila, K. (2008). Pemahaman konsep matematik dalam pembelajaran matematika. Prosiding Seminar Nasional Matematika dan Pendidikan Matematika, Jurusan Pendidikan Matematika Fakultas Matematika dan Ilmu Pengetahuan Alam Universitas Negeri Yogyakarta.

Yuriska, Mayasari dkk (2014). Penerapan teknik probing-prompting dalam Pembelajaran matematika siswa kelas viii Mtsn lubuk buaya padang Vol. 3 No. 1 (2014) Jurnal Pendidikan Matematika : Part 2 Hal 56-61 FMIPA $U N P$

National Council of Teachers of Mathematics. (2000). Principles and Standards for School Mathematics. Reston, VA: NCTM.

Oktavia, ayu. (2016). Analisis kesulitan mahasiswa dalam menyelesaikan Persamaan differensial tingkat satu. Jurnal : epints.ums.c.id

Ruseffendi. (2005). Dasar-dasar Penelitian Pendidikan dan Bidang Non-eksakta Lainnya. Bandung: Tarsito 